\section{What matters most? Evidence-based findings of health dimensions affecting the societal preferences for EQ-5D health states}

\author{
O que importa mais? Evidências empíricas das \\ dimensões que afetam as preferências sociais \\ para estados de saúde do EQ-5D
}

\author{
¿Qué es lo que más importa? Evidencias \\ empíricas sobre las dimensiones que afectan a las \\ preferencias sociales por los estados de salud en \\ EQ-5D
}

Monica Viegas Andrade 1 Kenya Valeria Micaela de Souza Noronha ${ }^{1}$ Ana Carolina Maia ${ }^{2}$ Paul Kind 3

\footnotetext{
${ }_{1}^{1}$ Centro de Desenvolvimento e Planejamento Regional Universidade Federal de Minas Gerais, Belo Horizonte, Brasil.

2 Instituto de Ciências Sociais Aplicadas, Universidade Federal de Alfenas, Alfenas, Brasil.

3 Academic Unit of Health Economics, Leeds Institute of Health Sciences, Leeds, England.

Correspondence

M. V. Andrade

Faculdade de Ciências

Econômicas, Centro

de Desenvolvimento e

Planejamento Regional,

Universidade Federal de Minas

Gerais.

Av. Antônio Carlos 6627,

Belo Horizonte, $M G$

31270-901, Brasil.

mviegas@cedeplar.ufmg.br
}

\begin{abstract}
This study analyzes how different health dimensions defined by the EQ-5D-3L instrument affect average individual preferences for health states. This analysis is an important benchmark for the incorporation of health technologies as it takes into consideration Brazilian population preferences in health resource allocation decisions. The EQ-5D instrument defines health in terms of five dimensions (mobility, daily activities, self-care activities, pain/discomfort, and anxiety/depression) each divided into three levels of severity. Data came from a valuation study with 3,362 literate individuals aged between 18 and 64 living in urban areas of Minas Gerais State, Brazil. The main results reveal that health utility decreases as the level of severity increases. With regard to health issues, mobility stands out as the most important EQ-5D dimension. Independently of severity levels of the other EQ-5D-3L dimensions, the highest decrements in utilities are associated with severe mobility problems.
\end{abstract}

Quality Adjusted Life Years; Health Evaluation; Health Technology Assessment

\section{Resumo}

Este estudo analisa como as diferentes dimensões dos estados de saúde definidas pelo instrumento EQ-5D-3L afetam, em média, as preferências dos indivíduos por estados de saúde. Essa análise é importante para balizar a incorporação de tecnologias em saúde uma vez que viabiliza considerar as preferências da população brasileira na decisão de alocação de recursos em saúde. O EQ-5D-3L define a saúde em cinco dimensões (mobilidade, atividades habituais, auto-cuidado, dor/desconforto e ansiedade/depressão) contendo três níveis de severidade. Os dados são provenientes de uma pesquisa inédita no Brasil que entrevistou 3.362 pessoas com idade entre 18 e 64 anos vivendo em áreas urbanas de Minas Gerais. Os principais resultados mostram que o decremento na utilidade dos indivíduos é crescente com o nível de severidade. No que se refere às dimensões de saúde, a mobilidade se destaca como a mais importante. Independentemente dos níveis de severidade das demais dimensões do EQ-5D, os maiores decrementos nas utilidades estão associados ao problema de mobilidade severa.

Anos de Vida Ajustados por Qualidade de Vida; Avaliação em Saúde; Avaliação de Tecnologias de Saúde 


\section{Introduction}

The main purpose of the health technology assessment (HTA) is to assist health policymakers in implementing more cost-effective technologies in order to allocate resources efficiently. HTA is an important tool in the analysis of the use of technologies at macro and micro levels. At the macro-level, HTA assists policymakers in formulating public health policies while at the micro-level it is mainly used to support the development of clinical practice guidelines and to assist physicians in efficiently combining individual technologies 1,2. Even though new health technologies contribute to improve population health, their uncritical use increases health expenditures and may have strong budget impacts. Ultimately this impact can threaten the access to health care services especially among low income groups $3,4,5,6,7,8$. The incorporation process of technologies in the healthcare sector presents peculiar characteristics. Firstly, it is quite dynamic and in general is supplier-induced demand. Because physicians usually have more diagnostic and prognostic information about patient conditions, information asymmetry performs an important role in this process. Secondly, unlike other markets, health technologies are barely substitutive. They tend to be accumulative which widen the technological alternatives in this sector. Thirdly, individuals will always demand more care even if there is no clinical evidence about its efficacy. When individuals are sick, the more care they get the better ${ }^{9,10}$.

The United States was one of the first countries to formally recognize the importance of HTA with the creation of the Office of Technology Assessment in 1973 by the US Congress. Despite the pioneering efforts of the US, the growth of HTA occurred at the beginning of the 1980s, mainly in European countries. This movement was stronger in countries with organized public healthcare systems such as Sweden, the Netherlands and the United Kingdom. Currently, Australia, Canada and the UK are at the forefront in the use of HTA in order to make decisions about incorporation or discharges of technologies in the healthcare sector 11,12,13,14,15

In Brazil, the demand for new health technologies is also growing mainly due to the aging process and changes in the epidemiological profile $16,17,18$. The incorporation of new health technologies depends on the institutional design of healthcare. In the Brazilian healthcare system, the private and public sectors are involved in both the funding and the delivery of health care services. The Brazilian Unified National Health System (SUS) was created by the Brazilian Fed- eral Constitution in 1988. The main principles of the SUS are universality, comprehensiveness and free of charge access. Therefore, in the public healthcare system, health is everyone's right and is the duty of the government. In the private sector, there are two sources of financing: out-ofpocket payments and health insurance 19 .

This institutional design imposes additional challenges for Brazilian policymakers. The incorporation process of new technologies is not centralized and the current regulation is limited to the services financed by SUS. In fact, the incorporation of new technologies tends to be endogenous. In this scenario, the economic rationality of the private sector can weaken the supremacy of the State in defining criteria for the incorporation of health technologies. As a result, loss of efficiency in resource allocation is often observed. Besides the issues involving efficiency, this institutional design generates asymmetries in the access to healthcare especially among individuals who have private health insurance coverage. The double access to the healthcare system among wealthier individuals may contribute to increase inequalities in the utilization of health services.

In this context, HTA is an important tool for ensuring the efficiency of the policy-making processes concerning the use of technology and financial sustainability of the healthcare system. The main methods used in this type of economic evaluation are: (1) cost-benefit, (2) cost-effectiveness and (3) cost-utility analysis. The main difference among the types of economic evaluation is the nature of the consequences stemming from the different alternatives that affect their measurement, valuation and comparison to costs. In cost-benefit analysis, health outcomes are expressed in monetary terms. In costeffectiveness analysis benefits are measured in natural health units such as number of life-years saved and number of hospitalizations avoided. In cost-utility analysis the incremental cost of an intervention is compared to incremental health improvements 8,12,20,21,22,23. Health outcomes are measured by a combination of mortality (alternatively length of life) and health-related quality of life measures. A usual approach to perform cost-utility analysis is the estimation of quality adjusted life years (QALY).

The use of QALYs requires the definition of societal preference weights for different health states 24,25 . There are several health-state classification systems that can be used in the construction of QALYs as for example Health Utility Index (HUI), Short-Form 36 Items (SF-36), Short-Form 6 Dimension (SF-6D) and EuroQol-5 Dimensions (EQ-5D). The difference among them is the number and type of health dimensions and levels of 
severity that each classification system takes into account $26,27,28,29,30,31,32$. EQ-5D is probably the most widely used generic measure of health status in measuring benefits for economic evaluation. Besides, this instrument is recommended by the National Institute for Health and Clinical Excellence (NICE) which is responsible to develop evidence-based guidelines on the most effective health technologies for the National Health Services (NHS) in the UK 33 . The EQ-5D instrument defines health in terms of five dimensions (mobility, daily activities, self-care activities, pain/discomfort, and anxiety/depression) divided into three (EQ-5D-3L) or five (EQ-5D-5L) levels of severity. In this paper the EQ-5D-3L version is used that considers the following categories of severity: no problem, moderate problem and severe problem. The combination of dimension and level of severity generates a total of 243 distinct health states 26,29,30,34,35,36,37,38. EQ-5D$5 \mathrm{~L}$ is a very recent instrument and its use is not widespread among countries making it difficult to compare internationally. In Brazil this study is the first attempt to estimate societal preference weights using EQ-5D. In this sense it is desirable to use the best known instrument. Besides, only recently studies validating the use of EQ-5D-5L have been published 39 .

The aim of this paper is to evaluate the effect of different EQ-5D health dimensions on individual health states valuation in Brazil. Which health dimension is more important for Brazilian health-related quality of life? This analysis is an important benchmark for the decision-makers in performing HTA. Health technologies usually improve health but it can have side effects that result in undesirable health states for society. Thus, the knowledge of health dimensions that generate the highest welfare gains can assist policy-makers when deciding about the implementation of new technologies.

\section{Method}

In Brazil, there are two studies that estimated societal preferences for the population. The first was conducted in the city of Porto Alegre in Rio Grande do Sul State and used the SF-6D instrument 28 . The valuation parameters were obtained using the standard gamble (SG) technique. Recently, a larger research was conducted in Minas Gerais State in order to estimate societal preferences weights for EQ-5D health states 40 . Weights were derived by applying the time trade-off (TTO) elicitation method to a subset of $102 \mathrm{EQ-}$ $5 \mathrm{D}$ health states. The advantage of TTO over SG is that TTO is easier to be applied and can be more readily understood. As Brazilian society is still marked by high socioeconomic heterogeneity and low education levels, TTO may have a better performance in evaluating health preferences. A more complex technique can introduce bias due to the difficulty faced by individuals in trying to understand the exercise.

The present paper will take advantage of this new database that provides information about individual preferences for EQ-5D health states in Minas Gerais 40. Minas Gerais is a large and heterogeneous state in the southeast region of Brazil and has a population of 20 million inhabitants, the majority residing in urban areas (Instituto Brasileiro de Geografia e Estatística. Censo demográfico 2010. http://www.ibge.gov.br). The state has the second largest economy of Brazil but presents great heterogeneity in terms of economic development and standards of living. An analysis of the Human Development Index (HDI) shows that socioeconomic disparities in Minas Gerais are similar to those observed across Brazil: in 2000, the HDI values for Minas Gerais cities ranged from 0.57 (in the northeast of the state) to 0.84 (southeast of the state) while in Brazil, the range was 0.64 (northeast of Brazil) and 0.82 (South of Brazil) 41. Due to its great diversity Minas Gerais is considered to be representative of Brazilian heterogeneity.

The EQ-5D descriptive classification defines a total of 243 distinct health states each of which is labeled with a unique five digit code. For example 11111 represents the full health state defined as having no problems in any dimension while 33333 represents the worst health state with extreme problems on all five dimensions. The EQ-5D Brazilian language version was culturally adapted and provided by the EuroQoL Group. The interview protocol followed a revised version 42 of the original Measurement and Value of Health (MVH) study 43 . This protocol has already been applied in deriving French population values for EQ-5D 34 and in a Korean valuation study 37. The Minas Gerais EQ-5D study 40 was designed so as to obtain values for 102 health states selected from the complete set of 243 states covering three broad severity categories defined by their proximity to the best possible health state. Mild states contain no level 3 problem on any dimension; severe states contain no level 1 problem on any dimension; moderate states lie within these two boundaries. These states were grouped into 26 blocks, with six health states in each comprising two mild, two moderate, and two severe states. Each individual evaluated one block of health states together with the logically best and worst health states (states 11111 and 33333 respectively) and 
the state "dead" - a total of nine states. Health state descriptions were presented on printed set of cards which were handed to the participant.

Individuals were first asked to describe their own health in terms of the EQ-5D classification system and to rate it using a Visual Analogue Scale (VAS) with endpoints of 0 and 100 corresponding to the worst and best imaginable health states. They were then asked to rank order the set of nine printed cards containing the health state descriptions from the best to worst. The cards were then shuffled and individuals were asked to rate them on the same 0 -100 VAS used to rate their own health. Respondents were instructed that each health state would last for 10 years followed by death. These exercises were performed before TTO in order to familiarize individuals with the description of health states.

The TTO elicitation protocol has been fully described elsewhere ${ }^{43}$. It essentially involves presenting participants with choices between two alternatives that comprise varying levels of quantity and quality of life. Health states can be evaluated as either better or worse than death. A double-sided time board is used with one side for health states considered better than dead and the other side for health states worse than dead. For states evaluated better than dead individuals establish the number of years $(x<10)$ in full health that provides them the same expected utility level as living ten years experiencing some specific health condition. The TTO value (V) is obtained dividing the length of time in full health by ten $V=\frac{x}{10}$. For states considered to be worse than dead individuals compare death with a choice that gives them 10-x years in some specific health state followed by $\mathrm{x}$ years $(\mathrm{x}<10)$ in full health. In this case the TTO value is given by $V=\frac{-x}{10-x}$. Indifference points in the TTO protocol were effectively established in terms of six month increments yielding a range of values from -19 to 1. In order to treat the asymmetric distribution of negative values, a monotonic transformation $V_{t}=\frac{V}{(1-V)}$, if $V<0$ was performed so as to alter the range of values to be -1 to 144 .

\section{Study design}

The target population was literate individuals aged between 18 and 64 years living in urban areas of Minas Gerais. A sample-size definition was based on the 2010 Brazilian Demographic Census (http: / /www.ibge.gov.br) with a margin of error equal to $3 \%$. In total, 3,362 individuals were recruited. The sample is representative by age and sex for the whole state and for three different regional levels of Minas Gerais: Belo Horizonte, metropolitan and non-metropolitan area. The sample was spatially distributed in order to take into account all macroregions of Minas Gerais and all planning areas of Belo Horizonte. Face-toface interviews were conducted in households in which one individual was selected. Sociodemographic information was recorded on all participants. Economic incentives were not offered to interviewees. All health states were evaluated by more than 100 individuals as recommended by Chuang \& Kind 45.

\section{Modeling}

Regression analysis was used to analyze the effect of health dimensions on individual EQ-5D health states valuation and to estimate the 243 EQ-5D health states. It should be noted that the states 11111 and dead are defined by virtue of the TTO procedure as having values of 1 and zero respectively. No inconsistent respondent data were excluded in the analysis. The choice of random effect model was based on the results of two tests, Hausman and Breush-Pagan tests ${ }^{46}$. Both mean absolute error (MAE) and the number of health states with absolute residuals over 0.05 were computed to as goodness of fit statistics. Statistical analyses were conducted using Stata 11.0 (Stata Corp., College Station, USA).

Dependent variable of all models was defined as 1 minus transformed TTO response (1-Vt). In order to evaluate which dimension and level of severity affect more the individual's health valuation, a set of 10 dummy variables for each level of severity and health dimensions were defined as follows: MO2 is equal to 1 if the mobility dimension is on level 2; MO3 is equal to 1 if the mobility dimension is on level 3; SC2 is equal to 1 if the self-care dimension is on level 2; SC3 is equal to 1 if the self-care dimension is on level 3; UA2 is equal to 1 if the daily activities dimension is on level 2; UA3 is equal to 1 if the daily activities dimension is on level 3; PD2 is equal to 1 if the pain/discomfort dimension is on level 2; PD3 is equal to 1 if the pain/discomfort dimension is on level 3; $\mathrm{AD} 2$ is equal to 1 if the anxiety/depression dimension is on level 2 and AD3 is equal to 1 if the anxiety/depression dimension is on level 3.

Other models including interaction terms were also tested: N2 is equal to 1 if any dimension is on level 2; N3 is equal to 1 if any dimension is on level 3; C3sq is equal to the square of the number of dimensions at level 3 and X5 is equal to 1 if five dimensions are on level 2 or 3 . 


\section{Results}

\section{Sample characteristics}

The socio-demographic and health characteristics of the achieved sample are displayed in Table 1. The sample is composed of literate individuals aged between 18 and 64 living in urban areas of Minas Gerais.

Sample weights were used to perform the frequency analysis. As the present study was based on quota sampling by age and sex, the distribution of these attributes is quite similar to the official surveys 40 . Around $45 \%$ of interviewed individuals have more than 11 years of schooling and $30 \%$ have less than 4 years. Distribution of health attributes are also similar to the results found elsewhere for the state of Minas Gerais 47.

This study is the first opportunity to analyze health conditions of a Brazilian population based on the EQ-5D descriptive system. The majority of individuals reported no problem in the five health dimensions: more than $90 \%$ of individuals do not have difficulties in performing self-care, daily activities, or any mobility problems; more than 55\% do not have any pain/discomfort or anxiety/depression. The prevalence of moderate problems is higher for two dimensions - pain/discomfort (38\%) and anxiety/depression (30\%). Despite the low prevalence, it is noticed that around $9 \%$ of individuals reported moderate problems in mobility and performing daily activities. Severe problems in all dimensions are less prevalent (lower than $5 \%$ ) in this population.

Among the investigated chronic diseases, hypertension is the most prevalent condition in this population (25\%) followed by spinal disease (18\%). Only $5 \%$ of individuals reported having suffered from diabetes.

Descriptive analysis of observed TTO values for directly evaluated EQ-5D health states

The study sample comprised 3,362 individuals of whom 177 respondents evaluated fewer than seven states in the TTO exercise and two individuals had all health states with missing values. In the majority of cases, these missing values were due to mistakes made by the interviewers such as the repetition of cards or errors in recording the board marker. These individuals were included in the data analysis but their non-valid responses were omitted. Table 2 displays the summary descriptive statistics of non-transformed and transformed TTO values for the directly evaluated EQ$5 \mathrm{D}$ heath states. All health states were evaluated by more than 124 individuals. Only the health state 33333 was evaluated by all individuals in
Table 1

Socio-demographic and health characteristics of the achieved sample in the Minas Gerais EQ-5D Valuation Study (in percentage). Minas Gerais State, Brazil.

\begin{tabular}{|c|c|}
\hline Characteristics & $\%$ \\
\hline \multicolumn{2}{|l|}{ Sex } \\
\hline Men & 48.42 \\
\hline Women & 51.58 \\
\hline \multicolumn{2}{|l|}{ Age group (years) } \\
\hline $18-34$ & 43.29 \\
\hline $35-49$ & 33.95 \\
\hline $50-59$ & 16.25 \\
\hline $60+$ & 6.50 \\
\hline \multicolumn{2}{|l|}{ Education level (years) } \\
\hline$<4$ & 29.23 \\
\hline $4-10$ & 24.55 \\
\hline 11 & 37.65 \\
\hline $12+$ & 8.54 \\
\hline \multicolumn{2}{|c|}{ Private health insurance plan } \\
\hline Yes & 31.36 \\
\hline No & 68.64 \\
\hline \multicolumn{2}{|l|}{ Self-reported health } \\
\hline Very good & 25.35 \\
\hline Good & 52.01 \\
\hline Fair & 20.49 \\
\hline Bad & 1.58 \\
\hline Very bad & 0.49 \\
\hline \multicolumn{2}{|c|}{ EQ-5D descriptive system } \\
\hline \multicolumn{2}{|l|}{ Mobility } \\
\hline No problem & 91.23 \\
\hline Some problem & 8.68 \\
\hline Incapacity & 0.09 \\
\hline \multicolumn{2}{|l|}{ Self-care } \\
\hline No problem & 97.59 \\
\hline Some problem & 2.06 \\
\hline Incapacity & 0.35 \\
\hline \multicolumn{2}{|l|}{ Usual activities } \\
\hline No problem & 89.85 \\
\hline Some problem & 9.81 \\
\hline Incapacity & 0.35 \\
\hline \multicolumn{2}{|l|}{ Pain/Discomfort } \\
\hline No problem & 57.71 \\
\hline Moderate & 38.35 \\
\hline Extreme & 3.94 \\
\hline \multicolumn{2}{|l|}{ Anxiety/Depression } \\
\hline No problem & 64.92 \\
\hline Moderate & 30.68 \\
\hline Extreme & 4.41 \\
\hline \multicolumn{2}{|c|}{ Chronic disease prevalence } \\
\hline Hypertension & 24.62 \\
\hline Depression & 14.36 \\
\hline Arthritis & 7.29 \\
\hline Kidney disease & 2.83 \\
\hline Diabetes & 5.55 \\
\hline Spinal disease & 17.64 \\
\hline Heart disease & 6.40 \\
\hline Cirrhosis & 0.22 \\
\hline Respiratory disease & 13.09 \\
\hline Tuberculosis & 0.37 \\
\hline
\end{tabular}


Table 2

Summary descriptive statistics for observed, non-transformed and transformed time trade-off (TTO) values.

\begin{tabular}{|c|c|c|c|c|c|c|c|c|c|c|c|c|c|c|c|}
\hline \multirow[t]{2}{*}{$\begin{array}{l}\text { Health } \\
\text { condition }\end{array}$} & \multirow[t]{2}{*}{$\mathbf{N}$} & \multicolumn{2}{|c|}{$\begin{array}{c}\text { Transformed } \\
\text { TTO }\end{array}$} & \multirow{2}{*}{$\begin{array}{l}\text { Worse } \\
\text { than } \\
\text { death } \\
\text { valua- } \\
\text { tions }\end{array}$} & \multicolumn{3}{|c|}{$\begin{array}{c}\text { Non-transformed } \\
\text { TTO }\end{array}$} & \multirow[t]{2}{*}{$\begin{array}{l}\text { Health } \\
\text { condition }\end{array}$} & \multirow[t]{2}{*}{$\mathbf{n}$} & \multicolumn{2}{|c|}{$\begin{array}{c}\text { Transformed } \\
\text { TTO }\end{array}$} & \multirow{2}{*}{$\begin{array}{l}\text { Worse } \\
\text { than } \\
\text { death } \\
\text { valua- } \\
\text { tions }\end{array}$} & \multicolumn{3}{|c|}{$\begin{array}{c}\text { Non-transformed } \\
\text { TTO }\end{array}$} \\
\hline & & Mean & SD & & Mean & SD & Minimum & & & Mean & SD & & Mean & SD & Minimum \\
\hline 11112 & 255 & 0.840 & 0.244 & 4 & 0.767 & 1.264 & -19.0 & 22232 & 127 & 0.331 & 0.567 & 36 & -0.122 & 2.585 & -19.0 \\
\hline 11121 & 253 & 0.869 & 0.193 & 4 & 0.866 & 0.221 & -1.2 & 22233 & 258 & 0.286 & 0.562 & 79 & -0.385 & 3.279 & -19.0 \\
\hline 11122 & 258 & 0.783 & 0.254 & 3 & 0.778 & 0.280 & -1.2 & 22313 & 129 & 0.455 & 0.447 & 15 & 0.208 & 1.911 & -19.0 \\
\hline 11123 & 127 & 0.758 & 0.327 & 4 & 0.469 & 2.488 & -19.0 & 22323 & 257 & 0.332 & 0.537 & 63 & -0.256 & 3.096 & -19.0 \\
\hline 11211 & 258 & 0.819 & 0.229 & 2 & 0.818 & 0.231 & -0.3 & 22332 & 381 & 0.149 & 0.551 & 140 & -0.512 & 2.979 & -19.0 \\
\hline 11212 & 258 & 0.799 & 0.244 & 3 & 0.797 & 0.253 & -0.8 & 22333 & 257 & 0.199 & 0.532 & 89 & -0.365 & 2.831 & -19.0 \\
\hline 11221 & 253 & 0.795 & 0.236 & 3 & 0.791 & 0.258 & -1.0 & 23113 & 258 & 0.483 & 0.465 & 31 & 0.157 & 2.286 & -19.0 \\
\hline 11222 & 261 & 0.715 & 0.317 & 13 & 0.708 & 0.346 & -1.0 & 23131 & 128 & 0.372 & 0.529 & 28 & -0.125 & 2.666 & -19.0 \\
\hline 11223 & 129 & 0.640 & 0.407 & 9 & 0.544 & 0.839 & -5.7 & 23132 & 129 & 0.334 & 0.504 & 24 & -0.180 & 3.002 & -19.0 \\
\hline 11232 & 124 & 0.556 & 0.448 & 19 & 0.504 & 0.612 & -3.0 & 23222 & 131 & 0.434 & 0.516 & 24 & -0.235 & 3.471 & -19.0 \\
\hline 11312 & 128 & 0.665 & 0.337 & 6 & 0.658 & 0.365 & -1.0 & 23223 & 257 & 0.254 & 0.548 & 78 & -0.431 & 3.291 & -19.0 \\
\hline 11313 & 129 & 0.636 & 0.377 & 7 & 0.599 & 0.534 & -3.0 & 23231 & 128 & 0.221 & 0.588 & 38 & -1.124 & 4.775 & -19.0 \\
\hline 11323 & 127 & 0.602 & 0.398 & 7 & 0.399 & 1.882 & -19.0 & 23232 & 256 & 0.207 & 0.560 & 89 & -0.505 & 3.294 & -19.0 \\
\hline 11332 & 128 & 0.504 & 0.450 & 18 & 0.185 & 2.486 & -19.0 & 23233 & 251 & 0.147 & 0.579 & 100 & -0.752 & 3.708 & -19.0 \\
\hline 12111 & 255 & 0.794 & 0.279 & 6 & 0.710 & 1.289 & -19.0 & 23311 & 127 & 0.349 & 0.550 & 28 & -0.247 & 3.096 & -19.0 \\
\hline 12112 & 513 & 0.746 & 0.319 & 13 & 0.707 & 0.599 & -5.7 & 13 & 127 & 0.188 & 0.547 & 0 & -0.857 & 4.208 & -19.0 \\
\hline 12121 & 258 & 0.755 & 0.288 & 5 & 0.742 & 0.359 & -1.9 & 23321 & 129 & 0.340 & 0.539 & 31 & 0.071 & 1.335 & -5.7 \\
\hline 12122 & 256 & 0.724 & 0.344 & 11 & 0.558 & 1.813 & -19.0 & 22 & 254 & 0.183 & 0.553 & 3 & -0.506 & 3.275 & -19.0 \\
\hline 12123 & 127 & 0.655 & 0.412 & 9 & 0.560 & 0.855 & -5.7 & 23323 & 256 & 0.146 & 0.550 & 100 & -0.617 & 3.179 & -19.0 \\
\hline 12211 & 256 & 0.737 & 0.314 & 7 & 0.655 & 1.284 & -19.0 & 23332 & 255 & 0.115 & 0.553 & 96 & -0.711 & 3.476 & -19.0 \\
\hline 12212 & 260 & 0.688 & 0.340 & 11 & 0.657 & 0.519 & -4.0 & 23333 & 255 & 0.042 & 0.566 & 112 & -1.227 & 4.330 & -19.0 \\
\hline 12221 & 257 & 0.718 & 0.334 & 8 & 0.605 & 1.386 & -19.0 & 31131 & 129 & 0.283 & 0.518 & 32 & -0.036 & 1.942 & -19.0 \\
\hline 12312 & 130 & 0.646 & 0.313 & 6 & 0.637 & 0.354 & -1.5 & 31213 & 130 & 0.303 & 0.516 & 29 & -0.131 & 2.546 & -19.0 \\
\hline 12313 & 128 & 0.530 & 0.435 & 14 & 0.230 & 2.472 & -19.0 & 31222 & 129 & 0.289 & 0.530 & 35 & -0.058 & 2.003 & -19.0 \\
\hline 12331 & 129 & 0.437 & 0.491 & 22 & 0.058 & 2.544 & -19.0 & 31311 & 128 & 0.361 & 0.516 & 25 & -0.034 & 2.523 & -19.0 \\
\hline 13123 & 127 & 0.548 & 0.423 & 14 & 0.363 & 1.822 & -19.0 & 31313 & 125 & 0.168 & 0.553 & 44 & -0.823 & 3.931 & -19.0 \\
\hline 13211 & 129 & 0.614 & 0.405 & 10 & 0.537 & 0.779 & -5.7 & 32111 & 127 & 0.322 & 0.544 & 31 & -0.191 & 2.672 & -19.0 \\
\hline 13222 & 129 & 0.470 & 0.478 & 20 & 0.266 & 1.837 & -19.0 & 32123 & 130 & 0.185 & 0.555 & 40 & -0.451 & 3.033 & -19.0 \\
\hline 13232 & 130 & 0.317 & 0.523 & 27 & -0.363 & 3.442 & -19.0 & 32223 & 255 & 0.091 & 0.571 & 108 & -0.854 & 3.677 & -19.0 \\
\hline 21111 & 256 & 0.789 & 0.295 & 5 & 0.710 & 1.278 & -19.0 & 32232 & 257 & 0.078 & 0.558 & 101 & -0.667 & 2.939 & -19.0 \\
\hline 21112 & 259 & 0.732 & 0.332 & 9 & 0.498 & 2.173 & -19.0 & 32233 & 256 & 0.060 & 0.513 & 110 & -0.576 & 2.847 & -19.0 \\
\hline 21121 & 257 & 0.722 & 0.342 & 9 & 0.553 & 1.803 & -19.0 & 32322 & 255 & 0.171 & 0.536 & 90 & -0.368 & 2.623 & -19.0 \\
\hline 21122 & 257 & 0.718 & 0.299 & 5 & 0.699 & 0.430 & -3.0 & 32323 & 258 & -0.006 & 0.543 & 133 & -0.620 & 2.370 & -19.0 \\
\hline 21123 & 128 & 0.569 & 0.482 & 20 & 0.347 & 1.897 & -19.0 & 32332 & 255 & -0.037 & 0.545 & 126 & -1.154 & 3.840 & -19.0 \\
\hline 21133 & 127 & 0.676 & 0.371 & 8 & 0.591 & 0.870 & -5.7 & 32333 & 254 & -0.086 & 0.546 & 136 & -1.689 & 4.745 & -19.0 \\
\hline 21211 & 258 & 0.737 & 0.302 & 9 & 0.730 & 0.330 & -1.0 & 33121 & 129 & 0.270 & 0.536 & 38 & -0.228 & 2.649 & -19.0 \\
\hline 21212 & 258 & 0.657 & 0.383 & 14 & 0.483 & 1.800 & -19.0 & 33122 & 127 & 0.263 & 0.546 & 36 & -0.487 & 3.507 & -19.0 \\
\hline 21221 & 257 & 0.679 & 0.354 & 14 & 0.637 & 0.568 & -4.0 & 33211 & 124 & 0.223 & 0.526 & 38 & -0.103 & 1.958 & -19.0 \\
\hline 21231 & 128 & 0.482 & 0.486 & 20 & 0.103 & 2.552 & -19.0 & 33213 & 258 & 0.065 & 0.528 & 108 & -0.693 & 3.252 & -19.0 \\
\hline 21311 & 130 & 0.683 & 0.343 & 7 & 0.640 & 0.653 & -5.7 & 33221 & 129 & 0.092 & 0.584 & 51 & -1.207 & 4.451 & -19.0 \\
\hline 21312 & 128 & 0.563 & 0.415 & 13 & 0.505 & 0.630 & -3.0 & 33222 & 253 & 0.038 & 0.574 & 121 & -0.901 & 3.531 & -19.0 \\
\hline 21313 & 127 & 0.575 & 0.413 & 11 & 0.369 & 1.858 & -19.0 & 33223 & 253 & 0.039 & 0.548 & 112 & -0.770 & 3.148 & -19.0 \\
\hline 21331 & 128 & 0.530 & 0.422 & 15 & 0.357 & 1.796 & -19.0 & 33231 & 129 & 0.031 & 0.553 & 61 & -0.974 & 3.811 & -19.0 \\
\hline 21332 & 128 & 0.402 & 0.520 & 27 & 0.112 & 1.945 & -19.0 & 33232 & 254 & 0.023 & 0.550 & 115 & -0.833 & 3.178 & -19.0 \\
\hline 22111 & 258 & 0.693 & 0.361 & 13 & 0.596 & 1.313 & -19.0 & 33233 & 255 & -0.055 & 0.562 & 130 & -1.193 & 3.713 & -19.0 \\
\hline 22112 & 257 & 0.615 & 0.413 & 20 & 0.474 & 1.432 & -19.0 & 33312 & 129 & 0.108 & 0.535 & 51 & -0.546 & 3.051 & -19.0 \\
\hline 22113 & 124 & 0.583 & 0.410 & 11 & 0.501 & 0.793 & -5.7 & 33313 & 126 & 0.048 & 0.534 & 54 & -0.725 & 3.110 & -19.0 \\
\hline
\end{tabular}

(continues) 


\begin{tabular}{|c|c|c|c|c|c|c|c|c|c|c|c|c|c|c|c|}
\hline \multirow[t]{2}{*}{$\begin{array}{l}\text { Health } \\
\text { condition }\end{array}$} & \multirow[t]{2}{*}{$\mathrm{N}$} & \multicolumn{2}{|c|}{$\begin{array}{c}\text { Transformed } \\
\text { TTO }\end{array}$} & \multirow{2}{*}{$\begin{array}{l}\text { Worse } \\
\text { than } \\
\text { death } \\
\text { valua- } \\
\text { tions }\end{array}$} & \multicolumn{3}{|c|}{$\begin{array}{c}\text { Non-transformed } \\
\text { TTO }\end{array}$} & \multirow[t]{2}{*}{$\begin{array}{c}\text { Health } \\
\text { condition }\end{array}$} & \multirow[t]{2}{*}{$\mathrm{n}$} & \multicolumn{2}{|c|}{$\begin{array}{c}\text { Transformed } \\
\text { TTO }\end{array}$} & \multirow{2}{*}{$\begin{array}{l}\text { Worse } \\
\text { than } \\
\text { death } \\
\text { valua- } \\
\text { tions }\end{array}$} & \multicolumn{3}{|c|}{$\begin{array}{c}\text { Non-transformed } \\
\text { TTO }\end{array}$} \\
\hline & & Mean & SD & & Mean & SD & Minimum & & & Mean & SD & & Mean & SD & $\begin{array}{l}\text { Mini- } \\
\text { mum }\end{array}$ \\
\hline 22121 & 253 & 0.617 & 0.398 & 26 & 0.449 & 1.803 & -19.0 & 33322 & 510 & -0.070 & 0.540 & 261 & -1.507 & 4.449 & -19.0 \\
\hline 22211 & 258 & 0.628 & 0.400 & 18 & 0.489 & 1.432 & -19.0 & 33323 & 381 & -0.046 & 0.556 & 188 & -1.338 & 4.108 & -19.0 \\
\hline 22221 & 129 & 0.510 & 0.500 & 21 & 0.275 & 1.895 & -19.0 & 33333 & 3328 & -0.235 & 0.494 & 2105 & -2.450 & 5.429 & -19.0 \\
\hline
\end{tabular}

SD: standard deviation.

the sample from which 34 presented non-valid information comprising 3,328 evaluations.

Non-transformed TTO values show an asymmetric distribution: the mean values range from 0.866 to -2.450 and the minimum can be equal to -19 . Therefore, while the values for betterthan-death states vary from 0 to 1 , the range for worse-than-death states is wider. To deal with this asymmetric distribution, worse-than-death states were transformed so as to be bounded by 0 and -1 .

Mean transformed TTO values range from $0.869(\mathrm{SD}=0.193)$ to $-0.235(\mathrm{SD}=0.494)$ for the 11121 and 33333 health states respectively. For mild health states, mean transformed TTO values vary from $0.869(\mathrm{SD}=0.193)$ to $0.615(\mathrm{SD}=$ 0.413 ). The percentage of individuals who classified mild health states as worse than death range from $1 \%$ (11211) to $10 \%$ (22121). For severe health states the maximum mean TTO value is 0.332 $(\mathrm{SD}=0.537)$ and the minimum is $-0.235(\mathrm{SD}=$ 0.494). Around $60 \%$ of individuals evaluated the health state 33333 as being worse than death. Values for moderate health states overlap both mild and severe ranges. The percentage of individuals who classified moderate health states as worse than death ranges from $3 \%$ (11123) to $47 \%$ (33231).

Overall, seven cards are given negative mean values indicating states worse than dead: 33333, 32333 , 33322, 33233, 33323, 32332 and 32323. The SD of transformed TTO values increases with the severity of the health state indicating greater heterogeneity in individual scores in poorer health states.

Table 3 displays the mean TTO health evaluation by each EQ-5D health dimension and level of severity for the whole sample and disaggregating by individual current health states. An individual health state is measured by the EQ5D descriptive system and self-reported general health. The last indicator originally comprises five response categories that were re-classified into three groups: (1) very good/good, (2) fair and (3) bad and very bad. For example, the first cell shows the average TTO evaluation (0.708) given by individuals with very good/good health to health states with mild mobility problems. It refers to the average TTO value of all health states with 1 in the mobility dimension independently of the severity level observed for the other health dimensions. As expected, the mean TTO values decrease by increasing the level of severity for all dimensions. When the whole sample is taken into account, the results emphasize the importance of mobility dimension to the health valuation. On the one hand health states presenting severe mobility problems (being confined in bed) are the only conditions for which the TTO mean value is negative $(-0.40)$. On the other hand health states without any mobility problems are given the highest weight (0.703) amongst all EQ$5 \mathrm{D}$ health dimensions/level of severity.

Among individuals without any problem or with moderate problems in either dimension, the results are similar to those found for the whole sample: health states with severe mobility problems are given the lowest mean TTO values while health states without mobility problems are better evaluated. The lowest mean TTO value for severe mobility problems is given by individuals experiencing moderate anxiety/depression (-0.069) whereas the highest value is given by individuals with moderate mobility problems $(0.023)$. The analysis for individuals with severe problems is more difficult since a small amount of individuals are classified in this health category across all dimensions.

In general, individuals reporting bad or very bad health tend to give a lower evaluation to all health dimensions/level of severity. For health states with severe and moderate problems, the highest mean TTO valuations are given by individuals with fair self-reported health. 
Mean time trade-off (TTO) values for each health dimension/ severity by current individual health status

\begin{tabular}{|c|c|c|c|c|c|c|c|c|c|c|c|c|c|c|c|}
\hline \multirow{3}{*}{$\begin{array}{l}\text { Health dimension/ } \\
\text { Level of severity }\end{array}$} & \multicolumn{15}{|c|}{ Mean health state evaluation } \\
\hline & \multicolumn{3}{|c|}{ Mobility } & \multicolumn{3}{|c|}{ Self-care } & \multicolumn{3}{|c|}{ Usual activities } & \multicolumn{3}{|c|}{ Pain/Discomfort } & \multicolumn{3}{|c|}{ Anxiety/Depression } \\
\hline & Mild & $\begin{array}{l}\text { Mod- } \\
\text { erate }\end{array}$ & Severe & Mild & $\begin{array}{l}\text { Mod- } \\
\text { erate }\end{array}$ & Severe & Mild & $\begin{array}{l}\text { Mod- } \\
\text { erate }\end{array}$ & Severe & Mild & $\begin{array}{l}\text { Mod- } \\
\text { erate }\end{array}$ & Severe & Mild & $\begin{array}{l}\text { Mod- } \\
\text { erate }\end{array}$ & Severe \\
\hline \multicolumn{16}{|l|}{ General health states } \\
\hline Fair & 0.691 & 0.459 & -0.012 & 0.652 & 0.435 & 0.054 & 0.665 & 0.407 & 0.089 & 0.579 & 0.432 & 0.052 & 0.589 & 0.436 & 0.108 \\
\hline Bad/Very bad & 0.613 & 0.374 & -0.089 & 0.593 & 0.376 & -0.056 & 0.485 & 0.359 & 0.009 & 0.527 & 0.307 & -0.021 & 0.631 & 0.282 & 0.017 \\
\hline \multicolumn{16}{|l|}{ Individual MO } \\
\hline Mild & 0.703 & 0.436 & -0.045 & 0.659 & 0.421 & 0.020 & 0.647 & 0.393 & 0.056 & 0.589 & 0.399 & 0.020 & 0.595 & 0.412 & 0.071 \\
\hline Moderate & 0.697 & 0.485 & 0.023 & 0.638 & 0.471 & 0.110 & 0.635 & 0.400 & 0.152 & 0.585 & 0.435 & 0.103 & 0.612 & 0.430 & 0.149 \\
\hline Severe & 0.563 & 0.533 & -0.021 & 0.588 & 0.275 & 0.130 & 0.600 & 0.563 & 0.168 & 0.610 & 0.406 & 0.121 & 0.450 & 0.325 & 0.323 \\
\hline Mild & 0.703 & 0.439 & -0.041 & 0.658 & 0.424 & 0.025 & 0.645 & 0.393 & 0.062 & 0.588 & 0.401 & 0.024 & 0.596 & 0.413 & 0.076 \\
\hline Moderate & 0.700 & 0.491 & 0.007 & 0.639 & 0.465 & 0.109 & 0.651 & 0.404 & 0.078 & 0.597 & 0.443 & 0.088 & 0.636 & 0.432 & 0.118 \\
\hline Severe & 0.635 & 0.569 & 0.155 & 0.624 & 0.447 & 0.250 & 0.743 & 0.391 & 0.339 & 0.571 & 0.454 & 0.286 & 0.529 & 0.513 & 0.289 \\
\hline \multicolumn{16}{|l|}{ Individual UA } \\
\hline Mild & 0.702 & 0.434 & -0.044 & 0.655 & 0.423 & 0.020 & 0.644 & 0.390 & 0.056 & 0.585 & 0.397 & 0.021 & 0.593 & 0.408 & 0.072 \\
\hline Moderate & 0.730 & 0.509 & 0.008 & 0.690 & 0.445 & 0.112 & 0.666 & 0.438 & 0.153 & 0.635 & 0.457 & 0.090 & 0.631 & 0.473 & 0.138 \\
\hline Severe & 0.432 & 0.484 & -0.066 & 0.534 & 0.431 & 0.026 & 0.602 & 0.333 & 0.011 & 0.524 & 0.407 & -0.026 & 0.587 & 0.327 & 0.070 \\
\hline \multicolumn{16}{|l|}{ Individual PD } \\
\hline Mild & 0.703 & 0.444 & -0.039 & 0.659 & 0.421 & 0.029 & 0.650 & 0.393 & 0.059 & 0.589 & 0.396 & 0.029 & 0.596 & 0.420 & 0.069 \\
\hline Moderate & 0.702 & 0.428 & -0.047 & 0.652 & 0.428 & 0.015 & 0.641 & 0.387 & 0.062 & 0.584 & 0.407 & 0.015 & 0.594 & 0.397 & 0.081 \\
\hline Severe & 0.710 & 0.506 & 0.027 & 0.688 & 0.456 & 0.117 & 0.623 & 0.468 & 0.169 & 0.635 & 0.449 & 0.102 & 0.626 & 0.468 & 0.163 \\
\hline \multicolumn{16}{|l|}{ Individual AD } \\
\hline Severe & 0.662 & 0.434 & -0.064 & 0.635 & 0.375 & 0.020 & 0.599 & 0.341 & 0.058 & 0.571 & 0.415 & -0.006 & 0.520 & 0.378 & 0.055 \\
\hline Total & 0.703 & 0.440 & -0.040 & 0.657 & 0.425 & 0.027 & 0.646 & 0.393 & 0.064 & 0.588 & 0.402 & 0.026 & 0.596 & 0.413 & 0.077 \\
\hline
\end{tabular}

AD: anxiety/depression dimension; MO: mobility dimension; PD: pain/discomfort dimension; SC: self-care dimension; UA: usual activities dimension.

Effect of health dimension and level of severity on EQ-5D health states valuation

Table 4 displays the results for random effect models. As the Hausman test was not significant (probability $>\chi^{2}=0.2453$ ), the null hypothesis was not rejected and the random effect model can be safely accepted. The Breush-Pagan test rejects the null hypothesis of homoscedasticity $\left(\chi^{2} p<0.001\right)$. The presence of heteroscedasticity favours the use of random effect models.

Five different specifications of random effect models were tested. The most parsimonious model (model 1) is based on main effects and includes only dummy variables for each health dimension and level of severity. More complex forms of the models (model 2 to model 5) include additional dummy variables to take into account the interaction effect of any dimension with moderate or extreme problems. All these models displayed similar results to the initial main effects specification with virtually identical goodness-of-fit statistics and the same number of states with a MAE exceeding 0.05 . Because the results were very similar among the models, the basic specification including only dummy variables for each health dimension and level of severity was selected. Besides some of interaction models presented inconsistencies: the N2 and N3 terms were negative.

All dummy coefficients are positive and significant at the $1 \%$ level. Since a dependent variable is defined as one minus the TTO value, coefficients are interpreted as a utility decrement relative to the perfect EQ-5D health state (11111). The constant is considered as an overall decrement independently of the health dimension and level of severity. In that way, health utility 
Results of random effect models estimated for linear-transformed time trade-off (TTO).

\begin{tabular}{|c|c|c|c|c|c|c|c|c|c|c|c|c|c|c|c|}
\hline \multirow[t]{2}{*}{ Variables } & \multicolumn{3}{|c|}{ Model 1} & \multicolumn{3}{|c|}{ Model 2} & \multicolumn{3}{|c|}{ Model 3} & \multicolumn{3}{|c|}{ Model 4} & \multicolumn{3}{|c|}{ Model 5} \\
\hline & Coeficient & & SD & Coeficient & & SD & Coeficient & & SD & Coeficient & & SD & Coeficient & & SD \\
\hline Mobility 2 & 0.128 & * & 0.007 & 0.135 & * & 0.007 & 0.130 & * & 0.007 & 0.119 & * & 0.008 & 0.132 & * & 0.007 \\
\hline Mobility 3 & 0.404 & * & 0.008 & 0.400 & * & 0.008 & 0.407 & $\star$ & 0.008 & 0.392 & * & 0.009 & 0.396 & * & 0.009 \\
\hline Self-care 2 & 0.121 & * & 0.007 & 0.128 & * & 0.007 & 0.122 & * & 0.007 & 0.111 & * & 0.007 & 0.123 & * & 0.007 \\
\hline Self-care 3 & 0.247 & * & 0.008 & 0.247 & * & 0.008 & 0.249 & * & 0.008 & 0.238 & * & 0.008 & 0.238 & * & 0.009 \\
\hline Usual activities 2 & 0.095 & $\star$ & 0.007 & 0.102 & * & 0.008 & 0.097 & * & 0.008 & 0.087 & $\star$ & 0.008 & 0.099 & * & 0.008 \\
\hline Usual activities 3 & 0.205 & * & 0.008 & 0.202 & * & 0.008 & 0.209 & * & 0.008 & 0.194 & * & 0.008 & 0.198 & * & 0.009 \\
\hline Pain/Discomfort 2 & 0.067 & * & 0.007 & 0.072 & * & 0.007 & 0.068 & * & 0.007 & 0.055 & * & 0.007 & 0.069 & * & 0.007 \\
\hline Pain/Discomfort 3 & 0.200 & * & 0.007 & 0.195 & $\star$ & 0.008 & 0.203 & * & 0.008 & 0.184 & * & 0.009 & 0.190 & * & 0.009 \\
\hline Anxiety/Depression 2 & 0.062 & * & 0.007 & 0.067 & * & 0.007 & 0.064 & * & 0.007 & 0.051 & * & 0.008 & 0.064 & * & 0.007 \\
\hline Anxiety/Depression 3 & 0.113 & * & 0.007 & 0.111 & * & 0.008 & 0.117 & * & 0.008 & 0.102 & * & 0.008 & 0.106 & * & 0.008 \\
\hline N3 & & & & & & & -0.013 & ns & 0.009 & & & & & & \\
\hline$\times 5$ & & & & & & & & & & 0.036 & * & 0.011 & & & \\
\hline C3sq & & & & & & & & & & & & & 0.002 & * & 0.001 \\
\hline Intercept & 0.054 & * & 0.010 & 0.077 & * & 0.012 & 0.054 & * & 0.010 & 0.079 & * & 0.012 & 0.052 & * & 0.010 \\
\hline R2 Overall & 0.365 & & & 0.365 & & & 0.365 & & & 0.365 & & & 0.365 & & \\
\hline Mean absolute error & 0.035 & & & 0.034 & & & 0.035 & & & 0.034 & & & 0.035 & & \\
\hline Number (of 102) >0.05 & 25 & & & 21 & & & 24 & & & 24 & & & 24 & & \\
\hline
\end{tabular}

Model 1: parsimonious RE model (controlling for main effects); model 2: controlling for main effects and dummy variable indicating presence of level 2 of severity in any dimension; model 3: controlling for main effects and dummy variable indicating presence of level 3 of severity in any dimension; model 4 : controlling for main effects and dummy variable indicating that all five dimensions are on level 2 or 3 ; model 5: controlling for main effects and a variable that it is the square of the number of dimensions at level 3; ns: not significant; SD: standard deviation.

* Significant at $1 \%$ level.

decreases by $5.4 \%$ due to any deviation from the perfect health state. The coefficients behave as expected showing a monotonic increase in value decrement with increasing severity for all health dimensions. The largest decrement is observed for severe mobility problems, which is around $40 \%$. Being confined in bed considerably decreases an individual's well-being. For three health dimensions (self-care, daily activities and pain/discomfort), the fact of having experienced severe problems decreases health utility by an amount of $20-25 \%$. For severe anxiety/depression, the decrease is lower at around $11 \%$. As for moderate problems, the utility decreases are around $12 \%$ for two dimensions (mobility and self-care) and $9 \%$ for daily activities. In case of pain/discomfort and anxiety/depression, having experienced moderate problems decreases utility by only $6 \%$.

The full set of preference weights for the 243 EQ-5D health states estimated using the most parsimonious specification is given in Table 5 . The results of estimated health parameters reflect the high decreases in utility due to mobil- ity problems. All the eleven worse-than-death health states present severe mobility problem in their composition. Twenty health states with the lowest mean estimated TTO values are characterized by the presence of this condition. This number more than doubles (to 46) when moderate mobility problem is also taken into account. Among the 95 health states with the highest TTO mean values only one presents severe mobility problem but it is compensated by the absence of moderate/severe problems in the other dimensions.

\section{Discussion}

This paper analyzes the Brazilian societal preferences for EQ-5D health states. The objective is to evaluate which health dimensions and level of severity matter more to the Brazilian population. The main results reveal that the decrement in health utility increase with severity level. Regarding health dimension, mobility stands out as the most important EQ-5D dimension. 
Table 5

Estimated mean preference weights for 24 3EQ-5D questionnaire health states based on the random effect model (main effects model).

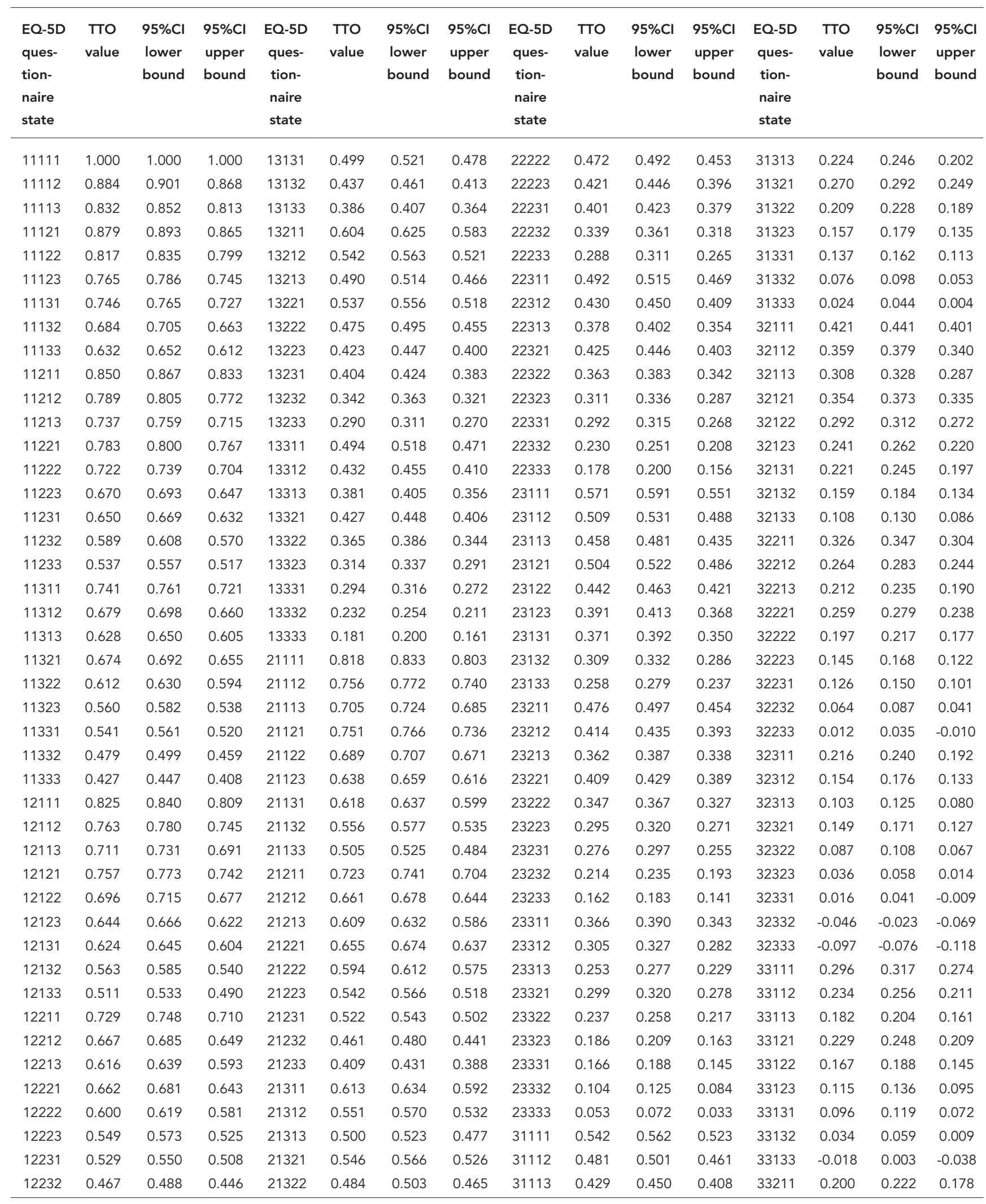

(continues) 


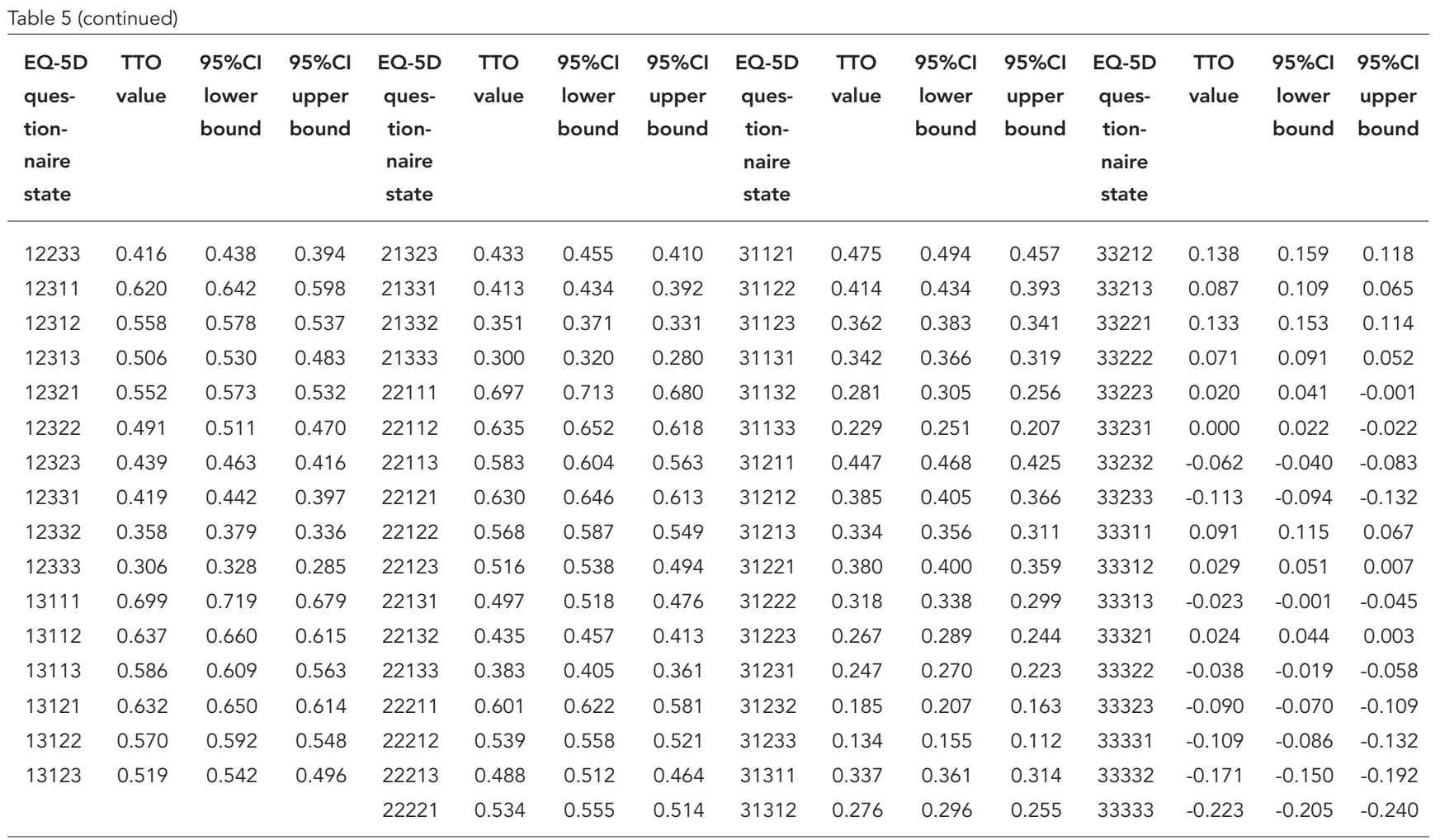

95\% Cl: 95\% confidence interval; EQ-5D: EuroQol five-dimensional; RE: random effect.

Independently of severity levels of the other EQ$5 \mathrm{D}$ dimensions, the highest decrements in utilities are associated to severe mobility problems at around $40 \%$. On the other hand, the highest TTO mean values are given to health states without any mobility problem. These results are also verified when the analysis is disaggregated by current individual health condition pointing out that health preferences do not depend on a disabling illness previously experienced by individuals.

The comparison with other countries valuation can give some clues as to whether these results are specific to the Brazilian population. In South America, only Argentina and Chile have thus far derived a set of social preference weights for use with EQ-5D 26,38. In Chile, unlike Brazil, decreases in health utility are associated with level of severity independently of the EQ-5D health dimension. The decrements are around $30-35 \%$ for all dimensions except anxiety/depression where the decrease is around $25 \%$. In Argentina, individuals tend to assign higher importance to three dimensions: mobility, self-care and pain/ discomfort. In this country, utility decrements are higher to health conditions presenting severe problems in mobility followed by the other two aforementioned dimensions.

The understanding of societal preferences for health states is important especially taking into account the aging population process that Brazil has experienced. Some studies on longevity and health have shown that gains in life expectancy are not accompanied by an extension of life expectancy free of disabilities. In fact, gains in longevity have increased the number of years of life experiencing some chronic diseases or disabilities 48 . The results of the present paper reinforce the debate about the uncritical use of new health technologies that only affect the extension of life. New health technologies increase the survival of individuals but at the same time can have negative effects on wellbeing by increasing the prevalence of morbidities. Our results give evidences that health preferences of the Brazilian population are strongly affected by the prevalence of severe health problems in especial mobility conditions.

In Brazil, HTA has been a concern since the 1980s with important government initiatives being introduced since 2004 with the creation of the Department of Science and Technology (DECIT) at the Brazilian Ministry of Health 49. DECIT is responsible for formulating and promoting a health technology assessment for the SUS. In 2008, the Brazilian Network for HTA (REBRATS) was created to subsidize the government in formulating HTA regulation and producing HTA research in Brazil. More recently, in 2011, the 
National Committee for Incorporation of Technologies in SUS (CONITEC) was founded under Federal Law n. 12,401/11. All new technologies that will be supplied in the public healthcare system must be evaluated by CONITEC. This is a great advancement for Brazilian legislation since cost-effectiveness parameters are now taken into account to determine the incorporation of new technologies. One challenge for this Committee is to consider the HTA health outcomes that take into account quality of life measures. The gains in longevity are not a guarantee to improve an individual's wellbeing.

It is important to notice that the sample of this study includes only individuals aged less than 64 years old and living in urban areas of Minas Gerais. As the prevalence of severe health problems is high among the elderly population, the exclusion of this age group can generate biased results. However the direction of the bias is not conclusive. The experience with severe health problems may affect individual evaluations in both directions. On the one hand, individuals with some severe health problems may be more adapted to their conditions and hence give higher scores to severe health states in the TTO exercise. On the other hand as these individuals know better about the difficulties of living with restrictions, their scores may be lower.

The Minas Gerais EQ-5D study takes several steps forward from the design of the original $\mathrm{MVH}$ protocol. First, to the best of our knowledge this is only the second occasion that a larger number of health states (102) were directly investigated in a household survey using the TTO exercise. Secondly, it is the first time that only nine health states are evaluated per individual. This innovation makes the evaluation exercise less demanding and individuals will be more likely to give responses that are not subject to fatigue or loss of attention. Finally, a large sample is investigated in a very heterogeneous population with representativeness for three different geographical areas. Hence, this study design allows the investigation of individual heterogeneity and differences among subgroups of the population in evaluating the health status using identical valuation procedures.

\section{Resumen}

Este estudio analiza cómo las diferentes dimensiones de la salud, definidas por el instrumento EQ-5D-3L, afectan, en promedio, las preferencias individuales por los estados de salud. Este análisis es un punto de referencia para la incorporación de tecnologías en salud, ya que hace posible considerar las preferencias de la población brasileña en las decisiones sobre la asignación de recursos de salud. El EQ-5D define la salud en cinco dimensiones (movilidad, actividades habituales, cuidado personal, dolor/malestar y ansiedad/depresión) con tres niveles de severidad. Los datos provienen de una investigación inédita en Brasil, que entrevistó a 3.362 personas entre 18 y 64 años y que viven en zonas urbanas de Minas Gerais. Los principales resultados muestran que la disminución en la utilidad de los individuos aumenta con el nivel de severidad. Con respecto a las dimensiones de salud, la movilidad se destaca como la más importante. Independientemente de los niveles de severidad de las otras dimensiones, los mayores decrementos en la utilidad están asociados con graves problemas de movilidad.

\section{Contributors}

M. V. Andrade coordinated the data collection; interpreted the data, carried out statistical analysis and drafted the manuscript. K. V. M. S. Noronha co-coordinated the data collection; interpreted data, carried out statistical analysis, drafted and provided critical revision for the manuscript. A. C. Maia and P. Kind contributed to the overall study conception, interpretation of data and the critical revision of the manuscript.

\section{Acknowledgments}

These findings are the result of work supported by FAPEMIG. The views expressed in this paper are those of the authors, and no official endorsement by FAPEMIG is intended or should be inferred.

\section{Conflict of interest}

None declared. 


\section{References}

1. Eisenberg JM. Ten lessons for evidence-based technology assessment. JAMA 1999; 282:1865-9.

2. Battista RN, Hodge MT. The evolving paradigm of health technology assessment: reflections for the millennium. CMAJ 1999; 160:1464-7.

3. Suen RMH. Technological advance and the growth in health care spending. Philadelphia: Economie d'Avant Garde; 2005. (Economie D'Avant Garde Research Report, 13).

4. Australian Government Productivity Commission. Impacts of advances in medical technology in Australia. Melbourne: Australian Government Productivity Commission; 2005. (Productivity Commission Research Report).

5. Aaron HJ, Schwartz WB, Cox M. Can we say no?: the challenge of rationing health care. Washington DC: Brookings Institution Press; 2005.

6. Okunade AA, Murthy VNR. Technology as a "major driver" of health care costs: a cointegration analysis of the Newhouse conjecture. J Health Econ 2002; 21:147-59.

7. Zarate V, Espinoza M, Castilho-Riquelme M. Evaluaciones económicas de tecnologías sanitarias: una perspectiva global para su aplicación en America Latina. Rev Peru Med Exp Salud Pública 2011; 28:535-9.

8. Nita ME, Secoli SR, Nobre M, Ono-Nita SK. Métodos de pesquisa em avaliação de tecnologia em saúde. Arq Gastroenterol 2009; 46:252-5.

9. Área de Economia da Saúde e Desenvolvimento, Secretaria Executiva, Ministério da Saúde. Avaliação de tecnologias em saúde: ferramentas para a gestão do SUS. Brasília: Ministério da Saúde; 2009.

10. Silva LK. Avaliação tecnológica em saúde: densitometria óssea e terapêuticas alternativas na osteoporose pós-menopausa. Cad Saúde Pública 2003; 19:987-1003.

11. Banta HD, Luce BR. Health care technology and its assessment: an international perspective. New York: Oxford University Press; 1993.

12. Área de Economia da Saúde e Desenvolvimento, Secretaria Executiva, Ministério da Saúde. Avaliação econômica em saúde: desafios para a gestão no Sistema Único de Saúde. Brasília: Ministério da Saúde; 2008.

13. Jackson TJ. Health technology assessment in Australia: challenges ahead. Med J Aust 2007; 187:263-4.

14. Neumann PJ. Using cost-effectiveness analysis to improve health care: opportunities and barriers. New York: Oxford University Press; 2005.

15. Hailey DM. Health technology assessment in Canada: diversity and evolution. Med J Aust 2007; 187:286-8.

16. Rodríguez-Wong LL, Carvalho JAM. O rápido processo de envelhecimento populacional do Brasil: sérios desafios para as políticas públicas. Rev Bras Estud Popul 2006; 23:5-26.

17. Carvalho JAM, Rodríguez-Wong LL. A transição da estrutura etária da população brasileira na primeira metade do século XXI. Cad Saúde Pública 2008; 24:597-605.
18. Berenstein CK, Wajnman S. Efeitos da estrutura etária nos gastos com internação no Sistema Único de Saúde: uma análise de decomposição para duas áreas metropolitanas brasileiras. Cad Saúde Pública 2008; 24:2301-13.

19. Ugá MAD Santos IS. An analysis of equity in Brazilian health system financing. Health Aff 2007; 26:1017-28.

20. Hurley J. An overview of the normative economics of the health sector. In: Culyer AJ, Newhouse JP, editors. Handbook of health economics. Amsterdam: Elsevier; 2000. p. 55-118.

21. Drummond MF, Sculpher MJ, Torrance GW, O'Brien BJ, Stoddart GL. Methods for the economic evaluation of health care programmes. 3rd Ed. New York: Oxford University Press; 2005.

22. Gold MR, Siegel JE, Russell LB, Weinstein MC. Cost-effectiveness in health and medicine. New York: Oxford University Press; 1996.

23. Murray CJL, Evans DB, Acharya A, Baltussen RMPM. Development of who guidelines on generalized cost-effectiveness analysis. Health Econ 2000; 9:235-51.

24. Klarman HJ, Francis J, Rosenthal G. Cost-effective analysis applied to the treatment of chronic renal disease. Med Care 1968, 6:46-54.

25. Robberstad B. QALYs vs DALYs vs LYs gained: what are the differences, and what difference do they make for health care priority setting? Nor Epidemiol 2005; 15:183-91.

26. Augustovski FA, Irazola VE, Velasquez AP, Gibbons L, Craig BM. Argentine valuation of the EQ-5D health states. Value Health 2009; 12:587-96.

27. Brazier JE, Harper R, Jones NMB, O'Cathain A, Thomas T, Usherwood T, et al. Validating the SF-36 health survey questionnaire: new outcome measure for primary care. BMJ 1992; 305:160-4.

28. Cruz LN, Camey SA, Hoffmann JF, Rowen D, Brazier JE, Fleck MP, et al. Estimating the SF-6D value set for a population-based sample of Brazilians. Value Health 2011; 14(5 Suppl 1):S108-14.

29. EuroQol: a new facility for the measurement of health-related quality of life. The EuroQol Group. Health Policy 1990; 16:199-208.

30. Kind P, Herdman M, Gudex C, Lloyd A, Janssen MF, Parkin D, et al. Development and preliminary testing of the new five-level version of EQ-5D (EQ-5D5L). Qual Life Res 2011; 20:1727-36.

31. Stevens KJ, Brazier JE, McKenna SP, Doward LC, Cork MJ. The development of a preference-based measure of health in children with atopic dermatitis. Br J Dermatol 2005; 153:372-7.

32. Zarate V, Kind P, Chuang L-H. Hispanic valuation of the EQ-5D health states: a social value set for Latin Americans. Value Health 2008; 11:1170-7.

33. National Institute for Health and Clinical Excellence. Guide to the methods of technology appraisal. London: National Institute for Health and Clinical Excellence; 2008.

34. Chevalier J, de Pouvourville G. Valuing EQ-5D using time trade-off in France. Eur J Health Econ 2013; 14:57-66. 
35. Lamers LM, McDonnell J, Stalmeier PF, Krabbe PF, Busschbach JJ. The Dutch tariff: results and arguments for an effective design for national EQ-5D valuation studies. Health Econ 2006; 15:1121-32.

36. Shaw JW, Johnson JA, Coons SJ. US valuation of the EQ-5D health states: development and testing of the D1 valuation model. Med Care 2005; 43:20320.

37. Lee YK, Nam HS, Chuang LH, Kim KY, Yang HK, Kwon IS, et al. South Korean time trade-off values for EQ-5D health states: modeling with observed values for 101 health states. Value Health 2009; 12:1187-93.

38. Zarate V, Kind P, Valenzuela P, Vignau A, OlivaresTirado P, Munoz A. Social valuation of EQ-5D health states: the Chilean case. Value Health 2011 ; 14:1135-41.

39. Janssen MF, Pickard AS, Golicki D, Gudex C, Niewada M, Sacalone L, et al. Measurement properties of the EQ-5D-5L compared to the EQ-5D-3L across eight patient groups: a multi-country study. Qual Life Res 2012; [Epub ahead of print].

40. Andrade MV, Noronha K, Kind P, Maia AC, Menezes RM, Reis CB, et al. Societal preferences for EQ$5 \mathrm{D}$ health states from a Brazilian population survey. Value in Health Regional Issues; in press.

41. Programa das Nações Unidas para o Desenvolvimento. Atlas do desenvolvimento humano no Brasil. Brasília: Programa das Nações Unidas para o Desenvolvimento; 2003.

42. Kind P. A revised protocol for the valuation of health states defined by the EQ-5D-3L classification system: learning the lessons from the $\mathrm{MVH}$ study. New York: Centre for Health Economics, University of York; 2009.
43. Gudex C. Time trade-off user manual: props and self-completion method. New York: Centre for Health Economics, University of York; 1994.

44. Dolan P. Modeling valuations for health states: the effect of duration. Health Policy 1996; 38:189-203.

45. Chuang LH, Kind P. The effect of health state selection on the valuation of EQ-5D. Med Decis Making 2010; 31:186-94.

46. Greene WH. Econometric analysis. 5th Ed. Upper Saddle River: Prentice Hall; 2003.

47. Instituto Brasileiro de Geografia e Estatística. Pesquisa Nacional por Amostra de Domicílios, PNAD 2008. Rio de Janeiro: Instituto Brasileiro de Geografia e Estatística; 2008.

48. Romero DE, Leite IC, Szwarcwald CL. Healthy life expectancy in Brazil: applying the Sullivan method. Cad Saúde Pública 2005; 21 Suppl:S7-18.

49. Amorim FF, Ferreira Júnior PN, Faria ER, Almeida KJQ. Avaliação de tecnologias em saúde: contexto histórico e perspectivas. Comun Ciênc Saúde 2010; 21:343-8.

Submitted on $31 / \operatorname{Jan} / 2013$

Final version resubmitted on 12/Jul/2013

Approved on 19/Jul/2013 